\title{
The Budgeting of Portuguese Public Museums: A Dynamic Panel Data Approach
}

\begin{abstract}
Maria Alberta Oliveira', João Coelhoii and Carlos Santos ${ }^{\mathrm{iii}}$
In this paper, the first panel on sources of funding for Portuguese publicly owned museums is explored. There has been little work in this field worldwide, and none for Portugal. Evidence in this paper seems contrary to that relating to the UK and to the US. We find that incremental budgeting still plays a major role on the funding of Portuguese museums, allowing for inefficient management and moral hazard: the interests of museums' management may diverge clearly from those of the authorities ruling them and from those of the general public. We also find that the ability to generate their own revenues plays no role in the funding allocated to museums every year. Budgeting is mainly determined by past operating costs. Policy changes seem to be advisable. The scarce relevance of museum patronage by the private sector makes a discussion of possible crowding out effects irrelevant in the current Portuguese context.
\end{abstract}

Keywords: Museums; incremental budgeting; moral hazard; dynamic panel data

JEL Codes: Z11, Z19, D73, C33

\section{Introduction}

The blossom of Cultural Economics over the past four decades has been accompanied by a vivid interest in the Economics of Museums as a major subfield of research. Montias (1973) was one of the pioneers in this area, with very influential contributions to several issues, some of which remain open to dispute even today. To begin with, he raised the issue of whether or not museums' management was concerned with the public interest, rather than with the interests of a subgroup of field specialists, using the Metropolitan Museum of Art, in New York, as an example. As it turns out, this moral hazard issue is one of the key concerns of this paper, albeit in an econometric perspective, rather than on a case study one.

On the other hand, Montias (1973) also revealed a keen concern with the strategic issue of collections management, suggesting an auction mechanism associated with museum patronage, to allow smaller museums to receive collection items that otherwise would just be stored in the basements of the major museums for a long time. Underlying this reasoning is the perception that lending works of art obtained through patronage is not always legally easy.

A second transversal issue that has been around since the early seventies is the question of whether or not entries should be paid. Peacock and Godfrey (1974), Netzer (1978), Throsby and Whithers (1979), Frey and Pommerehne (1989) are among the first contributors to this field. Although we shall not address the normative

\footnotetext{
' ISMAI, Maia Institute of Higher Education, and Research Unit UNICES. The author acknowledges financial support from Maiêutica, through the Research Unit UNICES.

ii Faculdade de Economia e Gestão, Universidade Católica Portuguesa.

iii Faculdade de Economia e Gestão, Universidade Católica Portuguesa and CEGE. Financial Support from the Fundação para a Ciência e Tecnologia, Lisboa, is gratefully acknowledged by the author. Corresponding author: csantos@porto.ucp.ptl
} 


\section{Oliveira, Coelho \& Santos}

issue of whether culture should or should not be a recipient of public grants, there are some close connections between this problem and that of moral hazard in museum management: Frey and Pommerehne (1989), for instance, make a strong case against such policies claiming they would reduce incentives for management to seek efficient practices. Rodriguez and Blanco (2006) have recently developed a most interesting contract theory model where the source of income of the museum (namely subsidies versus own revenues) is associated with moral hazard problems, and the design of a proper incentives mechanism is suggested.

Finally, a number of studies have assessed the positive externalities associated with the consumption of cultural goods, and museum visits in particular. These externalities are both static and inter-temporal and have been used by some to argue in favour of the existence of a market failure, thus providing an incentive for public subsidies to be granted to museums (for a discussion, see, inter alia, Peacock (1969), Throsby (1994) and Bailey and Falconer (1998)).

In spite of this rapid growth in the Economics of Museums, there has been a markedly less significant research on the side of empirical and econometric studies therein, namely from the point of view of their financing and budgeting strategies. Most empirical studies concerning the Economics of Museums have focused on attempts to estimate demand, production and cost functions. In particular, with respect to the Portuguese case, the only econometric study in the field of the Economics of Museums pertains to an attempt to estimate a visitors' demand function (Matos 1996).

With respect to museums' funding, Hughes and Luksetich (1999) and Maddison (2004) remain the fundamental and almost only empirical references. Hughes and Luksetich (1999) have looked at a cross section of US museums and tried to identify the interactions between different types of funding. In particular, they were interested in assessing whether or not government subsidies would crowd out private donations. Instead they found evidence of a strong positive influence of government funding on private contributions. Taking a different approach, Maddison (2004) has looked at a panel of UK museums. Whilst he did not have the necessary data to test the crowding out hypothesis, his research allowed him to assess whether or not there was evidence of Granger causality of some types of revenues and costs on government grants. Maddison (2004) has also attempted to look at the issue of the type of budgeting strategy pursued by museums: incremental budgeting, performance-based budgeting or activity-based budgeting.

In this paper, we follow a similar approach to the one in Maddison (2004) in that we explore a new panel on sources of funding for Portuguese museums. This is to our knowledge the first attempt to conduct such a study for Portugal, and the first work ever to be conducted on this data set. Like Maddison (2004), we use a dynamic panel model specification, but our econometric approach differs markedly: firstly, we test for panel unit roots, a problem that Maddison (2004) does not address; secondly, we allow for the possibility that there might be heteroscedasticity and autocorrelation in the data (again a discussion that is absent in Maddison (2004) and that is shown to be crucial in, e.g., Arellano and Bond (1991)). Finally, we conduct a more rigorous assessment of model specification by also looking at global significance by means of a Wald test (again following more closely the seminal paper by Arellano and Bond (1991)). Our conclusions shall differ markedly from those obtained for UK museums, implying different policy recommendations. 


\section{Oliveira, Coelho \& Santos}

This paper is organized as follows. The next section presents some evidence pertaining to the economic relevance of the cultural sector in general, and of museums in particular, in the Portuguese economy. Section 3 discusses the data used. Section 4 discusses the econometric methodology and the estimation results. Section 5 concludes.

\section{A Literature Review on the Economic Relevance of Museums in Portugal}

The economic relevance of cultural activities in EU countries varies widely, but remains a relatively undisputed fact. In Portugal, the weight of family cultural expenditures on GDP was of about 4\% during the nineties (Neves 2004), whilst the share of public expenditure in culture to total public expenditure varied between $0.75 \%$ and $1 \%$, over the same period. In 2003, 632.687.000 Euro were spent with cultural activities by the Portuguese government.

As far as museums are concerned, employment in museums or in museum related activities represented $0.8 \%$ of total business employment, and $37 \%$ of total cultural employment, in Portugal, in 2003. Not accounting for tourism, the cultural sector is responsible for $1.5 \%$ of employment in Portugal, a value that is not too dissimilar to the ones observed, for example, in Spain, France, Belgium and Poland: $2.1 \%, 2 \%$, $2.2 \%$ and $1.7 \%$, respectively (Eurostat 2006 ).

The vast majority of Portuguese museums (in fact, more than 60\%) are publicly owned and publicly managed (either by a local authority, a regional government, or the central government). Evidence shows that high budget public museums (those with more than $498.800 €$ of annual expenditures) are usually managed by the central government, whilst low budget museums (less than $49.880 €$ of annual expenditures) are usually managed by local authorities, namely city councils. Clearly, most Portuguese museums exhibit annual expenditures of less than 249.399€ (about $65.8 \%$ of all Portuguese museums). Only $1.8 \%$ have annual expenditures in excess of 498.800€ (Neves 2004).

When assessing Portuguese museums, a common budgeting problem seems to emerge from the surveys: $63.1 \%$ of all museums indicate that they do not elaborate their own budget (OAC 2005). Rather, responsibility for allocating funds to different museums rests with the proper governing authority (local, regional or central), in the case of publicly owned museums. This raises the issue of whether incremental budgeting strategies are being pursued. With an incremental budgeting strategy, the needs of each museum are simply assessed on the basis of the amount of money the museum has spent in the past. Therefore, increases in expenditures are likely to increase future grants. This option clearly raises efficiency issues: on the one hand, museums are likely not to engage in more efficient cost reducing management practices, since it is perceived that these will ultimately reduce the funds available in years to come; on the other, it is not uncommon, with incremental budgeting, that managers seek to spend the full amount they are allocated each year, as savings might translate into lower allocation of funds in the coming future.

There is a wide consensus in the public finance literature that incremental budgeting practices might lead to lock-ins in the time paths of grant allocations: once these are awarded to inefficient and wasteful museums, they are likely to be awarded to them for a number of years. Adding to this, there is scope for a moral hazard issue, 


\section{Oliveira, Coelho \& Santos}

whereby museums' management might pursue interests that are not those of the general public and, clearly, not those of the authority ruling over them (whether local, regional or central). There are no incentives for management to behave differently.

The alternative to incremental budgeting would be the pursuit of either activity-based budgeting or performance-based budgeting. The first would emphasize capital expenditures and new acquisitions of collections, rather than operating costs. The second would make funds allocation an explicit function of some measure of performance the museums should target (eg. a high number of visitors, showing a compromise between management and the general public interests). From a normative point of view, a case could be made in favour of performance-based budgeting, since public grants are ultimately supported by taxes levied on the general public.

A final remark worth noticing is the irrelevance of museum patronage in Portugal. Indeed, in spite of a series of legislative changes favouring private donors, cultural patronage is mainly focused on other cultural activities (namely music festivals). Between 1986 and 1996, the weight of museum patronage in Portuguese cultural patronage, is only $2.6 \%$ (Santos et al. 1998).

Combining the low levels of funding involved in museum patronage and the overwhelming majority of publicly owned museums, it seems to be the case that a discussion of possible crowding out of private grants by public subsidies makes little sense for Portugal. In fact, the discussion on whether or not the budgeting of public museums is correctly designed to provide incentives to pay attention to the public interest, and to avoid inefficient management, seems much more relevant (in contrast with the problem addressed by Hughes and Luksetich (1999)).

\section{Data}

We have used I.N.E. ${ }^{1}$ data for this study. The sample consists of yearly data, comprising the period from 1983 to 1998. The choice not to use more recent data had to do with the change in criteria and methodologies that I.N.E. has used to collect museums data in subsequent periods, making a coherent analysis difficult if not impossible.

The sample contains information with respect to costs, revenues and number of visitors for 10 Portuguese Museums ${ }^{2}$ in the sample period. In particular, we have used the following variables (we provide the abbreviations we shall use for each variable in the econometric model, and a description of what it stands for; where relevant, further information about the variable is provided):

- $\quad d s d$ (donations and subsidies) concerns the amount of funding each museum has received each year under the form of public or private grants and subsidies (a discrimination between public and private sources of funding is not possible with I.N.E. data alone ${ }^{3}$ );

- $\quad r p$ (receipts) is the amount of revenues each museum has generated by itself, in any given year (Although all museums in our sample are public, they do charge an admission fee. Nonetheless, this is largely symbolic, and aiming at avoiding the overcrowding of museums, rather than to cover costs. The main revenues considered here, apart from the admission fees, are related to 


\section{Oliveira, Coelho \& Santos}

restaurant and bar services, as well as to souvenir shops. All museums considered in the sample offer restaurant and bar services, and all of them have souvenir shops).

- rem (staff remuneration) concerns the total amount of salaries each museum has paid, per year;

- $\operatorname{coc}$ (cost of new collections) is, for each museum, the cost it has endured, in any given year, with respect to the purchase of new collections;

- iequip (investment in new equipments) refers to investments made by a museum, in any sample year, (excluding the purchase of new collections);

- epr (extraordinary revenues) is the amount of revenue a museum has generated in a given year by conducting studies and research it has been ordered by the government or by other museums, and by engaging in repair work;

- od stands for other expenditures (a residual class, once one has taken account of the cost of new collections, other investments and labour costs);

- $\quad$ nvisits: is the number of visitors a museum has had in any year ${ }^{4}$.

All cost and revenue variables are expressed in Portuguese escudos and are evaluated at constant prices (with 1998 being the reference year). It should also be pointed out that all the museums in the sample were, during the period surveyed, publicly owned. In particular, the sample comprises museums from a variety of fields: art, science and technology, natural history, archaeology, anthropology and history, among others.

\section{Methodology and Estimation Results}

\subsection{Descriptive Statistics}

Table (1) reports some descriptive statistics pertaining to the variables we have chosen to include in the econometric model.

Table 1: Descriptive Statistics for the model variables

\begin{tabular}{|l|l|l|}
\hline Variable & Mean & Std. Deviation \\
\hline Dsd & 326595.7 & 523643.5 \\
\hline$R p$ & 235751.4 & 396219.8 \\
\hline rem & 368190.6 & 475934.2 \\
\hline Coc & 13713.08 & 20187.39 \\
\hline lequip & 64431.27 & 101319.9 \\
\hline Epr & 26180.88 & 49615.61 \\
\hline Od & 137702.2 & 247080 \\
\hline Nvisits & 648942.3 & 655821.6 \\
\hline
\end{tabular}

Three fundamental conclusions seem to arise from table (1). Firstly, considering all the cost variables (rem, coc, iequip and od), labour costs clearly represent, on average, the heaviest burden over museums' finances. In fact, on average, wages represent a fraction of about $63 \%$ of total costs. Other expenditures (od) stand for 


\section{Oliveira, Coelho \& Santos}

$23.6 \%$, whilst equipment investment is only $11 \%$ of the total cost. The purchase of new collections is the least significant share of museums' costs. In other words, for the average Portuguese museum in an average year, labour costs are nearly $2 / 3$ of all the costs it has to endure. Since labour costs and other expenditures are, by definition, operating costs, it is easy to see that the bulk of the average museum income is diverted from such activities as improving the quality of exhibitions or augmenting the space for visitors (see Foster and Maddison (2003) for a discussion on the costs of congestion).

Secondly, table (1) also reveals that the income generated by the average museum in an average year is only $40.4 \%$ of the museum's total costs. Clearly this is insufficient even to face operating expenditures (in fact it is even insufficient to meet the average yearly wage bill). Portuguese museums in the sample, and during the sample period, clearly rely on external funding to meet nearly $60 \%$ of all costs. In short, table (1) strongly suggests there is a wide scope for improvement in the management practices of Portuguese museums, which are most likely to be inefficient (see Mairesse and Vanden Eeckaut (2004) for a discussion on museum efficiency).

Finally, table (1) also suggests there is a wide variability in all of the sample variables, with particular emphasis on $d s d$. This might indicate one should proceed with caution in the econometric model analysis, in particular with respect to the possibility of heteroscedasticity in the estimation residuals. On the other hand, such in sample variability points also to the possibility of unobserved heterogeneity amongst museums, suggesting econometric procedures that are capable of coping with such a problem. It is well known in the econometrics literature that not accounting for unobserved heterogeneity leads to biased and inconsistent estimation.

\subsection{Econometric Results}

The baseline model we have used is given by:

$$
\begin{aligned}
d s d_{i, t}= & \beta_{1}+\beta_{2} d s d_{i, t-1}+\beta_{3} \text { rem }_{i, t-1}+\beta_{4} r p_{i, t-1}+\beta_{5} \operatorname{coc}_{i, t-1}+\beta_{6} \text { epr }_{i, t-1} \\
& +\beta_{7} \text { iequip }_{i, t-1}+\beta_{8} \text { od }_{i, t-1}+\beta_{9} \text { nvisits }_{i, t-1}+v_{i}+\varepsilon_{i, t}
\end{aligned}
$$

It is convenient to partition the right-hand side variables in two blocks: $\left(d s d_{i, t-1}: \mathbf{x}_{i, t-1}^{*}\right)$. $\mathbf{x}_{i, t-1}^{*}$ is therefore a vector of $(k-1)$ regressors, which are assumed to be strictly exogenous: $\operatorname{cov}\left(x_{i, t}^{*} ; v_{s}^{i}\right)=0, \forall_{t, s}$ (footnote 8 , ahead, will provide a justification for this assumption). A similar assumption, with respect to a very similar set of variables, is made in Maddison (2004). Notwithstanding, Maddison (2004) provides no support nor discussion for the strict exogeneity of regressors he assumes.

Unobserved individual heterogeneity, $v_{i}$, is assumed to be time-invariant. Possible stochastic trends in any of the regressors or in the dependent variable are tested for rather than assumed (for an overview on panel unit root tests, see Banerjee (1999)). The Levin, Lin and Chu (2002) panel unit root test was conducted for each variable. This test is preferable to the one suggested by Hadri (2000) given the small panel dimensions. The Levin, Lu and Chu (2002) test assumes that all museums share the 


\section{Oliveira, Coelho \& Santos}

same autoregressive coefficient, but it does allow for museum specific effects, time effects and time trends. It also allows for autocorrelation in the residuals.

The null hypothesis refers to nonstationarity. In particular, the null postulates that the variable is integrated of order one. Table (2) reports these results ${ }^{5}$.

Table 2: p-values for the LLC panel unit root test (with constant but without trend)

\begin{tabular}{|l|l|}
\hline Variable & $\mathrm{p}$-value \\
\hline Dsd & 0.0148 \\
\hline Rem & 0.0000 \\
\hline Rp & 0.0000 \\
\hline Coc & 0.0004 \\
\hline Epr & 0.0000 \\
\hline lequip & 0.0000 \\
\hline Od & 0.0000 \\
\hline Nvisits & 0.0000 \\
\hline
\end{tabular}

Several competing specifications of the auxiliary regression (with deterministic trend and constant, and with no constant nor trend) were also tried, but the results do not seem to be sensitive to the specification chosen. In particular, table (2) suggests that, at a $5 \%$ significance level, the null hypothesis is always rejected, leading us to conclude that all variables in the panel are stationary.

The rejection of the null hypothesis in the Levin, Lin and Chu (2002) test has led us to a different model specification than that used in Maddison (2004). Indeed, whilst the author felt the need to include a time-varying intercept to accommodate possible non-stationarities, we choose to perform a proper panel unit root test. Therefore, the aforementioned rejection of the null for every variable, has led us to choose a timeinvariant intercept.

The suggested model in equation (0.1) was estimated using the Arellano and Bond (1991) GMM approach ${ }^{6}$. We are well aware that the semi-asymptotic results developed by the authors were obtained assuming that $N \rightarrow \infty$ whilst $T$ is fixed. Their approach is therefore said to be designed for large $N$ and small $T$ panels (Bond 2002). Much of the subsequent literature on dynamic panel data has followed the same path (see, inter alia, Ahn and Schmidt (1995), and Arellano and Honore (2001)). However, as in Maddison (2004), we were faced with the difficulty of estimating a dynamic model from a panel of observations where the cross-sectional dimension is itself small. This problem has led to a number of Monte Carlo studies in the literature. Kiviet (1995) and Harris and Mátyás (1996) have argued that the performance of GMM estimators in this setting varies with the dimensions of the panel and the true parameter values.

Notwithstanding, Judson and Owen (1999) have shown that the GMM estimator is the best option for values of $N$ and $T$ that are close to the ones in our sample. The Least Squares Dummy Variable estimator (LSDV) seems better than the GMM estimator for larger time dimensions, namely $T \geq 30$. Notwithstanding, GMM seems to be preferable, even in comparison with the Anderson-Hsiao (1981) estimator, for the small time dimension considered. All these procedures seem to be dominated by the corrected LSDV estimator (LSDVC). This alternative is not considered in Maddison 


\section{Oliveira, Coelho \& Santos}

(2004). Notwithstanding, many computational aspects remain unclear with respect to the LSDVC estimator (namely with respect to unbalanced panels, among other issues).

In short, we choose the same estimation procedure as Maddison (2004) in his assessment of the financing of British museums, by proceeding with the GMM estimator. The results from Judson and Owen (1999) provide reliable reassurance for this option.

It should be noticed that the specification of equation (0.1) is different from that in Hughes and Luksetich (1999), as their data set was cross sectional. Therefore, although we cannot perform the same type of crowding out analysis as they did, due to insufficient information, we are in a better position to assess budgeting strategies and Granger causality.

After first differencing, it is clear that the unobserved individual-specific heterogeneity drops from equation (0.1). Using the suggested partition of the right-hand side variables we obtain ${ }^{7}$ :

$$
\Delta d s d_{i, t}=\beta_{2} \Delta d s d_{i, t-1}+\boldsymbol{\beta} \Delta \mathbf{x}_{i, t-1}^{*}+\Delta \varepsilon_{i, t}(0.2)
$$

First order autocorrelation may exist in the residuals of equation (0.2). However, Arellano and Bond (1991) point out that the researcher's concern should be with second order autocorrelation. We improve on Maddison (2004), in the sense that we explicitly take into account the possibility of heteroscedasticity and autocorrelation in the estimation residuals. In particular, robust standard errors are used (as advised in Arellano and Bond (1991), when there is the risk of heteroscedasticity), and residual autocorrelation is explicitly tested for.

We also use a Wald test to assess global significance of the suggested model, whilst this was not a concern in Maddison's (2004) analysis. Finally, we take into account the possibility of over identifying restrictions, through a Sargan test, something that this is absent from the discussion in Maddison (2004) ${ }^{8}$.

Table (3) reports the estimation results. The robust standard errors option was used.

Table 3: Estimation results and individual significance observed test statistics with matching p-values.

\begin{tabular}{|l|l|l|l|l|}
\hline Variables & Coefficient & $\begin{array}{l}\text { Robust } \\
\text { standard error }\end{array}$ & $\begin{array}{l}\text { Observed test } \\
\text { statistic }\end{array}$ & $p$-value \\
\hline$d s d$ & 0,362994 & 0,0399594 & 9,08 & 0,000 \\
\hline$r p$ & $-0,0494201$ & 0,1658742 & 0,3 & 0,766 \\
\hline rem & 0,454962 & 0,0923602 & 4,93 & 0,000 \\
\hline coc & 0,1530771 & 1,742032 & 0,09 & 0,93 \\
\hline epr & 0,5686054 & 0,348094 & 1,63 & 0,102 \\
\hline iequip & 0,6294475 & 0,2790177 & 2,26 & 0,024 \\
\hline od & 0,327079 & 0,1731178 & 1,89 & 0,059 \\
\hline nvisits & $-0,0351583$ & 0,0515095 & $-0,68$ & 0,495 \\
\hline Constant & 17103,56 & 5363,446 & 3,19 & 0,001 \\
\hline
\end{tabular}




\section{Oliveira, Coelho \& Santos}

The estimated model reported in table (3) is globally significant, as can be inferred from the observed Wald test statistic of 180265.58 (clearly bigger than the critical value obtained from the $\chi_{(8)}^{2}$ distribution). Furthermore, using Arellano and Bond's $m_{2}$ statistic for second order autocorrelation, we conclude that the associated $p$-value is 0.1644 . This is higher than the significance level used (5\%), so we do not reject the null of no second order autocorrelation ${ }^{9}$. Results for Sargan's test of over-identifying restrictions are not discussed in the main text since the selected model in equation (0.2) was estimated with robust standard errors: the asymptotic distribution of this test statistic is unknown with the robust model.

Inference on individual coefficients proves to be most interesting, mainly in confrontation with the results of Maddison (2004). Clearly, the most noticeable difference is the absence of individual significance of the $r p$ variable, in the Portuguese case. That is, the museums' own revenues do not play a role when private and public agents make decisions on the grants to be awarded. It is true that the estimated coefficient has a negative sign, indicating that both public and private donors might perceive the ability of the museums to generate revenues as a surrogate for their own grants. Notwithstanding, the variable is clearly insignificant, leading to the fundamental conclusion that the budgeting of public Portuguese museums, as far as donors are concerned, does not rest on their own ability to generate revenues. This is a strong suggestion that incremental budgeting routines play a role in the decision making process. The budgeting practices provide no incentives for museum management to focus on obtaining other sources of income.

The fact that the number of visitors is insignificant, from a statistical viewpoint, rules out performance-based budgeting. In this respect our conclusion is similar to that of Maddison (2004) concerning British Museums. Nonetheless, one should bear in mind that visitor numbers are often an inaccurate measure. Creigh-Tyte and Selwood (1998) discuss this issue in depth. Edwards (1996) finds that there is an overstatement of visitor numbers in the British Museum of about 35-40\% per year. On the positive side, visitor numbers are the only output indicator, as far the museum activity goes, available for the Portuguese case.

Furthermore, the fact that the lagged value of grants is statistically significant and that the estimated coefficient is positive (even at the $1 \%$ significance level) points in the direction of a certain degree of persistence in the award of grants and subsidies. This again indicates that routines play a role in budgeting practices.

One should also notice that labour costs are statistically significant as is equipment investment. We disagree with Maddison (2004) in the interpretation that lagged equipment investment is a tantamount to activity-based budgeting. It can also be interpreted as an influence of past budgets on the current year budget. When considered jointly, the relevance of the lagged labour costs, lagged grants, and even lagged other expenditures (if one is to notice that its $p$-value only marginally exceeds the $5 \%$ significance level) does seem to reinforce the notion that publicly owned Portuguese museums operate on the basis of incremental budgeting.

On the other hand, if one was to worry with causality, in the sense of statistical precedence, as defined by Granger (1969), the most striking conclusion of our analysis is that whilst past expenditures seem to have an influence on the current budget, the museums ability to generate revenues is irrelevant for that purpose. 


\section{Oliveira, Coelho \& Santos}

There is a large scope for inefficiencies in the use of public resources in this scenario. The government is depriving itself of a fundamental tool to induce less wasteful management by public museums.

\section{Conclusion}

By conducting the first econometric assessment of the interaction between sources of museum funding in Portugal, this paper has some new findings that should be of interest both to academics and policy-makers. The most striking of these is the clear evidence in favour of incremental budgeting practices in Portuguese museums. In a contrast with the findings of Maddison (2004) for UK museums, it is clear that the ability to generate its own revenues does not influence the grants a Portuguese museum is to receive in the future. This provides a wide scope for inefficiencies, where management is likely to pursue its own agenda, as there is no perceived penalty for not taking the public interest into account. Moreover, the statistical significance of lagged grants suggests the possibility of inefficient lock-ins, whereby past grants to inefficient museums are perpetuated through time.

In short, the empirical results in section 4 are coherent with the available evidence for museums in Portugal discussed in section 2. Most museums do not make their own budgets: rather these are the received from the relevant authority as a result of reported past expenditures. That being the case, there is clearly scope for a moral hazard problem, as more current expenditures are perceived as generating higher grants in the future.

Finally, the discussion of possible crowding out effects makes little sense when museum patronage is relatively insignificant in Portugal (evidence in section 2 shows that cultural patronage mainly seeks other activities).

A fundamental policy implication seems to arise from this paper. The budgeting process of Portuguese museums should be revised. Firstly, incremental budgeting should be replaced by zero based budgets or by activity-based budgets. Incremental budgets institutionalize a wrong system of incentives where it appears to exist a payoff to wasteful museum managers. The design of a proper incentives mechanism might be helped by a reduction on the share of publicly owned museum's in Portugal, or by the adoption of hybrid management solutions (see Schuster (1998) for a discussion on hybridization of museum management). In any event, it is clear that museums should be responsible for producing and providing a justification for their own budgets, rather than relying on a formula whereby the current year's grants are equal to last year's expenditure plus some incremental factor.

\section{Endnotes}

\footnotetext{
${ }^{1}$ The Portuguese Office for National Statistics.

${ }^{2}$ All of these are Public Museums, managed by local authorities. They are similar in size, suggesting no heterogeneity issues, although such possibility shall be into due account in the subsequent econometric analysis.

${ }^{3}$ As discussed previously, this should be irrelevant in the Portuguese case.

${ }^{4}$ Given the description provided for the rp variable, it is clear there is a very low correlation between that variable and the number of visitors. Hence, multicollinearity concerns are excluded from our econometric analysis.
} 


\section{Oliveira, Coelho \& Santos}

${ }^{5}$ Levin, Lin and Chu (2002) provide Monte Carlo evidence strongly suggesting that a very good approximation to the asymptotic distribution of their test statistic is already obtained with $T=25$ and $N=10$. Albeit our time dimension being shorter than theirs, the very low $p$-values of table (2) - in all cases but one rounded to zero at the fourth decimal - imply that the observed test statistics in our sample are such that for a $5 \%$ significance level, this is very unlikely to cause any major inference issues, under rejecting the hypothesis of a unit root.

${ }^{6}$ All estimation results reported in this paper were obtained using STATA 9.2. The instruments used were the lagged values of the dependent variable, and current and lagged values of all strictly exogenous regressors.

7 Time invariant parameters, such as the intercept, may be recovered since we have a sufficient number of instruments (Arellano \& Bond 1991).

${ }^{8}$ Results for the Sargan test, however, shall not be reported in the main text, as they refer to versions of the Arellano and Bond (1991) procedure that rest upon the use of conventional standard errors, instead of the robust ones used in the estimation results presented. Notwithstanding, if one was to proceed with estimation, without taking into account the possibility of heteroscedasticy, and to use conventional standard errors, evidence shows that the Sargan test for over-identifying restrictions fails to reject the null ( $p$-value is 0.1448 ). A fundamental implication of this is that the assumption of strict exogeneity with respect to the variables in $\mathbf{x}_{i, t-1}^{*}$ is validated. Differently, Maddison (2004) did not report any evidence in support of his strict exogeneity assumption.

${ }^{9}$ It could be pointed out that we also conclude in favour of the absence of first order positive autocorrelation, on the basis of Arellano and Bond's $m_{1}$ statistic.

\section{References}

Ahn, SC \& Schmidt, P 1995, 'Efficient estimation of models for dynamic panel data'. Journal of Econometrics, vol. 68, pp. 5-27.

Anderson, TW \& Hsiao, C 1981, 'Estimation of dynamic models with error components', Journal of the American Statistical Association, vol. 76, pp. 589606.

Arellano, M \& Bond, S 1991, 'Some Tests of Specification for Panel Data: Monte Carlo Evidence and Application to Employment Equations', Review of Economic Studies, vol. 58, pp. 277-297.

Arellano, M \& Honore, B 2001, 'Panel Data Models: Some Recent Developments', in JJ Heckman \& EE Leamer (eds.), Handbook of Econometrics, vol. 5, North Holland.

Bailey, S \& Falconer, P 1998, 'Charging for Admission to Museums and Galleries: A Framework for Analysing the Impact on Access', Journal of Cultural Economics, vol. 22, pp. 167-177.

Banerjee, A 1999, 'Panel Data Unit Roots and Cointegration: An Overview', Oxford Bulletin of Economics and Statistics, Special Issue, pp. 607-629.

Bond, SR 2002, 'Dynamic panel data models: a guide to micro data methods and practice', Portuguese Economic Journal, vol. 1, pp. 141-162.

Creigh-Tyte, S \& Selwood, S 1998, 'Museums in the UK: some evidence on Scale and Activities', Journal of Cultural Economics, vol. 22, pp. 151-165.

Edwards, A 1996, The British Museum: A Fundamental Review of the Museum's Operation, The British Museum, London.

Foster, T \& Maddison, D 2003, 'Valuing Congestion Costs in the British Museum', Oxford Economic Papers, vol. 55, pp. 173-190.

Frey, BS \& Pommerehne, WW 1989, Muses and Markets: Explorations in the Economics of Arts, Basil Blackwell, Oxford.

Granger, C 1969, 'Investigating Causal Relations by Econometric Models and Cross Spectral Methods', Econometrica, vol. 37, pp. 424-438.

Hadri, K 2000, 'Testing for Stationarity in Heterogenous Panel Data', Econometrics Journal, vol. 3, pp. 148-161. 


\section{Oliveira, Coelho \& Santos}

Harris, M \& Mátyás, L 1996, 'A Comparative Analysis of Different Estimators for Dynamic Panel Data Models', Monash University, Mimeo.

Hughes, P \& Luksetich, W 1999, 'The relationship among Funding Sources for Art and History Museums', Nonprofit Management and Leadership, vol. 10, pp. 2138.

Levin, A, Lin, C \& Chu, C 2002, 'Unit Root Tests in Panel Data: Asymptotic and Finite Sample Properties', Journal of Econometrics, vol. 108, pp. 1-24.

Judson, R \& Owen, A 1999, 'Estimating Dynamic Panel Data Models: a Guide for Macroeconomists', Economics Letters, vol. 65, pp. 9-15.

Kiviet, J 1995, 'On Bias Inconsistency and the Efficiency of Various Estimators in Dynamic Panel Data Models', Journal of Econometrics, vol. 68, pp. 53-78.

Matos, C 1996, 'A Procura de Visitas a Museus - Duas Vias Alternativas de Análise', Universidade do Porto, Faculdade de Economia, Mimeo.

Maddison, D 2004, 'Causality and Museum Subsidies', Journal of Cultural Economics, vol. 28, pp. 89-108.

Mairesse, F \& Vanden Eeckaut, P 2004, 'Musem Assessment and FDH technology Towards a Global Approach', Journal of Cultural Economics, vol. 18, pp. 261286.

Montias, JM 1973, 'Are Museums Betraying the Public's Trust?', Museum News, vol. 51 (May/June), pp. 25-31.

Netzer, D 1978, 'The Subsidized Muse. Public Support for the Arts in the United States', The Economic Journal, vol. 88, no. 352, pp. 871-872.

Neves, JS 2004, O Panorama Museológico em Portugal [2000-2003], Observatório das Actividades Culturais e IPM/RPM, Lisboa, Portugal.

O.A.C. 2005, Contribuições para a Formulação de Políticas Públicas no Horizonte 2013 Relativas ao Tema Cultura, Identidade e Património: Relatório Final, Lisboa, Portugal.

Santos, MLL, Casanova, JL, Carreiras, H, Mata, J \& Alves, N 1998, 10 Anos de Mecenato Cultural em Portugal, Observatório das Actividades Culturais, col. OBS Pesquisas no. 1, Lisboa, Portugal.

Peacock, AT 1969, 'Welfare Economics and Public Subsidies to the Arts', The Manchester School of Economics and Social Studies, vol. 37, no. 4, pp. 323335.

Peacock, AT \& Godfrey, C 1974, 'The Economics of Museums and Galleries', The Lloyds Bank Review, vol. 111, pp. 17-28.

Rodriguez, JP \& Blanco, VF 2006, 'Optimal Pricing and Grant Policies for Museums', Journal of Cultural Economics, vol. 30, no. 3, pp. 169-181.

Schuster, J 1998, 'Neither Public Nor Private: The Hybridization of Museums', Journal of Cultural Economics, vol. 22, no. 2-3, pp. 127-150.

Throsby, D 1994, 'The Production and Consumption of Arts: A View of Cultural Economics', Journal of Economic Literature, vol. 32, no. 1, pp. 1-29.

Throsby, D \& Withers, G 1979, The Economics of the Performing Arts, St. Martin's, New York, U.S.A. 